\title{
Effect of Gamma Irradiation on Nutritional Quality Parameters of Dehusked Foxtail Millet (Setaria italica (L.) Beauv.)
}

\author{
Mala $^{1}$, R.S. Roopa Bai ${ }^{1}$, Udaykumar Nidoni ${ }^{1}$, H. Sharanagouda ${ }^{1}$ and S.G. Hanchinal ${ }^{2}$ \\ ${ }^{1}$ Department of Processing and Food Engineering, College of Agricultural Engineering, \\ University of Agricultural Sciences, Raichur 584 104, Karnataka, India \\ ${ }^{2}$ Department of Agricultural Entomology, AC, UAS, Raichur, India \\ *Corresponding author
}

\section{A B S T R A C T}

\section{Keywords}

Gamma irradiation,

Dehusked foxtail

millet, Quality

parameters, Cobalt

-60 (60Co),

Storage, Post

harvest loss

\section{Article Info}

Accepted:

07 October 2019

Available Online:

10 November 2019
This study evaluated the effect of gamma irradiation on nutritional quality parameters of dehusked foxtail millet such as moisture content, carbohydrates, crude protein, crude fat, crude fibre, total ash, total phenols, tannin and phytic acid. Dehusked foxtail millet samples of $500 \mathrm{~g}$ each, packaged in polyethylene terepthalate packaging material (PET, 400 gauge), were irradiated using gamma Cobalt - $60\left({ }^{60} \mathrm{Co}\right)$ radiator. The packaged samples were evenly exposed to different irradiation doses $\left[\mathrm{T}_{1}(0.25), \mathrm{T}_{2}(0.50), \mathrm{T}_{3}(0.75), \mathrm{T}_{4}(1.00), \mathrm{T}_{5}(1.25)\right.$, $\mathrm{T}_{6}(1.50), \mathrm{T}_{7}(1.75)$ and $\mathrm{T}_{8}(2.00) \mathrm{kGy}$ and unirradiated sample served as control. The irradiated and unirradiated (control) dehusked foxtail millet were stored for a period of 6 months at room temperature. The results showed that irradiated dehusked foxtail millet with a concentration of $1.75 \mathrm{kGy}$ reduced the moisture content, crude protein, crude fat, crude fibre, tannin and phytic acid and increased the carbohydrates, total ash and total phenols compared to unirradiated samples. Hence, it was concluded that the application of irradiation technology is a promising technology with no adverse effects on nutritional quality and to reduce the post harvest loss.

\section{Introduction}

Foxtail millet (Setaria italica) is native to Southern Asia and is considered as one of the oldest cultivated millets (Oelkeet al., 1990). Foxtail millet belongs to family Poaceae and subfamily Panicoideae. Nutritional value of foxtail millet (Setariaitalica) per $100 \mathrm{~g}$ of edible portion contains moisture $12.5 \mathrm{~g}$, protein $12.3 \mathrm{~g}$, lipid $4.3 \mathrm{~g}$, carbohydrate 60.1 $\mathrm{g}$, ash $1.2 \mathrm{~g}$, fat $4.3 \mathrm{~g}$, dietary fibre $9.0 \mathrm{~g}$, calcium $3.1 \mathrm{~g}$, minerals $3.3 \mathrm{~g}$, vitamins and thiamine $590 \mathrm{mg}$ (Malleshi and Desikachar, 1985). It contains fair amount of phenols, which is a strong antioxidant. Most millets with hulls have excellent storage properties 
and can be kept for 4 - 5 years in simple storage facilities such as traditional granaries. This is because the seeds are protected from insect attack by the hard hull covering the endosperm. Simple milling process might trigger oxidative rancidity and development of off flavor during storage of both grits and flour, so it is better to grind the flour right before it is to be used.

Generally, chemical fumigants are used to disinfest grains (Arthur, 1996). However, continuous application of these pesticides has a negative impact either on the environment or human health (Cherry et al., 2005). Therefore, the industry has been forced to explore nonchemical alternatives. One possible alternative would be the application of irradiation (Khalid and Manjeet, 2016).

Irradiation is the process of exposing food to ionizing radiation to destroy microorganisms, bacteria, viruses or insects that might be present in the food (Fombang et al., 2005). It is already recognized as a technically feasible method and safe alternative technology to chemical methods, which maintains the quality and nutritional characteristics of stored products as well as their shelf-life (Jyoti et al., 2009). Apart from disinfestation, irradiation can cause subsequent changes in food components; especially in carbohydrates, proteins, lipids and vitamins.

In lipids, it has been found that a relatively high dose of irradiation would give rise to a relatively milder decomposition compared to decomposition produced by normal cooking temperature (Nawar, 1983). Irradiation has also been successfully used for the inhibition and removal of food allergens and antinutritional factors such as saponins and tannins (Al-Kaisey et al., 2002; Byun et al., 2002; Diehl 2002; Bhat et al., 2007). FAO/IAEA/WHO Joint Expert Committee has recommended that the food items irradiated up to an average dose of $10 \mathrm{kGy}$ can be accepted as safe from the health angle and do not present any toxicological hazards. In 2001, FDA determined that food should be prepackaged before irradiation. It protects irradiated food from recontamination and maintains the quality of food.

The irradiated foods are labeled with "Radura" logo and along with the words "Processed by irradiation method" (Nagat et al., 2015).

Foxtail millet is commonly infested by stored pests like rice moth, Corcyra cephalonica which is also known to infest cereals, millets, oil seeds, pulses, etc (Nirmala et al., 2009).

After dehusking of foxtail millet due to the exposure to ambient conditions, rancidity sets in rapidly reducing the shelf-life drastically. In this context, the objective of this research was to study the effect of gamma irradiation on quality parameters of dehusked foxtail millet.

\section{Materials and Methods}

\section{Raw material}

The foxtail millets (Variety: HMT 100-1) were procured from the seed unit, University of Agricultural Sciences, Raichur.

\section{Cleaning and destoning of foxtail millets}

The foxtail millet grains were cleaned using specific gravity separator and destoner. Later, the cleaned materials were fed into millets destoner for removing stones and other impurities present in the grain mass.

\section{Dehusking of foxtail millets}

The centrifugal double disc type dehusker was used for dehusking of foxtail millets. The cleaned and destoned foxtail millets grain was fed into the millet dehusker. 


\section{Packaging of dehusked foxtail millets}

In 2001, the Food and Drug Administration (FDA) recommended that, the foods should be pre-packaged before irradiation. Because food once irradiated, it can be prone to recontamination unless appropriately packaged. Hence, the dehusked foxtail millets (500 g each) were packaged in polyethylene terephtalate (PET, 100 micron) before irradiation for further storage studies.

\section{Irradiation of dehusked foxtail millets}

Dehusked foxtail millets samples of $500 \mathrm{~g}$ each, packaged in polyethylene terepthalate (PET, 100 micron), were irradiated using gamma Cobalt - $60\left({ }^{60} \mathrm{Co}\right)$ radiator. The packaged samples were evenly exposed to different irradiation doses of $\mathrm{T}_{1}(0.25)$, $\mathrm{T}_{2}(0.50), \quad \mathrm{T}_{3}(0.75), \quad \mathrm{T}_{4}(1.00), \quad \mathrm{T}_{5}(1.25)$, $\mathrm{T}_{6}(1.50), \mathrm{T}_{7}(1.75)$ and $\mathrm{T}_{8}(2.00) \mathrm{kGy}$ with a dose rate of $9.50 \mathrm{kGy} / \mathrm{h}$ and unirradiated sample served as control.

\section{Storage quality evaluation}

\section{Proximate composition of dehusked foxtail millets}

The moisture content of the foxtail millets was determined by following AOAC, 2005 (Method No. 945.43) using hot air oven drying method. The estimation of carbohydrates in foxtail millets was carried out as per standard procedure outlined by AOAC, 2005 (Method No. 975.14). The nitrogen content of foxtail millets was estimated by using Kjeltech apparatus, (Model: D-40599, Behr Labor Technik GmbH, Germany) (AOAC, 2005; Method No. 950.36). Crude fat of foxtail millets was determined by using Soxhlet apparatus (AOAC, 2005; Method No. 922.06). The crude fibre content of foxtail millets was determined by following sequential acid and alkali hydrolysis method using Fibra-Plus (Make: Pelican Equipments; Model: FES-08S) apparatus (AOAC, 2005; Method No. 962.09 E). The total ash content of foxtail millets was determined as per the standard procedure (AOAC, 2005; Method No. 925.23) by using muffle furnace (MAC; MSW-251).

\section{Anti-nutritional properties of dehusked foxtail millets}

\section{Total phenols}

The concentration of total phenols in foxtail millets was estimated with Folin Ciocalteau reagent. The alcoholic extraction of $100 \mu \mathrm{l}$ was added to $900 \mu$ of distilled water and 0.5 $\mathrm{ml}$ of Folin Ciocalteau reagent and mixed thoroughly for $3 \mathrm{~min}$. After $3 \mathrm{~min}$, one $\mathrm{ml}$ of $15 \% \mathrm{Na}_{2} \mathrm{CO}_{3}$ solution was added, the contents were mixed and the volume was made upto 10 $\mathrm{ml}$ with distilled water. After $45 \mathrm{~min}$ of incubation at room temperature, the absorbance was measured at $750 \mathrm{~nm}$ against the reagent blank. Gallic acid was used as the standard for preparing the calibration curve $(0.05-0.4 \mathrm{mg} / \mathrm{ml})$. The sample absorbance was interpolated on the standard graph and the total phenolic compound (such as gallic acid) was calculated and expressed as $\mathrm{mg} \mathrm{GAE} / \mathrm{g}$ (Sun et al., 2007).

\section{Tannin}

Tannin content of foxtail millets was determined by Folin Denis method described by Price et al., (1978). One gram of sample was dissolved in $10 \mathrm{ml}$ distilled water and agitated, left to stand for $30 \mathrm{~min}$ at room temperature. The sample was centrifuged and the extract was recovered, then $2.5 \mathrm{ml}$ of the supernatant was dispersed into $50 \mathrm{ml}$ volumetric flask. Similarly, $2.5 \mathrm{ml}$ of standard tannic acid solution was dispersed into a separate $50 \mathrm{ml}$ flask. One milliliter Folin Dennis reagent was measured in flask 
followed by $2.5 \mathrm{ml}$ of saturated $\mathrm{Na}_{2} \mathrm{CO}_{3}$ solution. The mixture was diluted to $50 \mathrm{ml}$ by distilled water in the flask and incubated for $90 \mathrm{~min}$ at room temperature. The absorbance of sample was measured at $250 \mathrm{~nm}$ with the reagent blank at zero. To calculate the concentration of tannin present in the sample, a graph of absorbance versus concentration of tannic acid was plotted along with a standard curve generated from the analysis of tannic acid. The percentage tannin was calculated by using the equation given below.

$$
\text { Tannin } \quad(\%)=\frac{\mathrm{X}}{\mathrm{W}} \times 100
$$

Where,

$\mathrm{X}=$ Concentration of tannic acid from standard graph, ppm

$\mathrm{W}=\mathrm{Weight}$ of sample, $\mathrm{g}$

\section{Phytic acid}

The phytic acid of foxtail millets was determined by using the procedure described by Wheeler and Ferrel (1971). Half gram of sample was poured into $250 \mathrm{ml}$ conical flask. One hundred milliliters of $2 \%$ conc $\mathrm{HCl}$ was used to soak the sample in the conical flask for $3 \mathrm{~h}$ and then filtered through a double layer filter paper. Fifty milliliters filtrate was placed in a $250 \mathrm{ml}$ beaker and $10 \mathrm{ml}$ of distilled water was added to give proper acidity.

Ten milliliters of $0.3 \%$ ammonium thiocyanate solution was added to sample solution as indicator and titrated with standard iron chloride solution which contained $0.00195 \mathrm{~g}$ iron $/ \mathrm{ml}$ and the end point was signified by brownish-yellow colouration that persisted for 5 min. The percentage of phytic acid was calculated by using the following equation.

Phytic acid $(\%)=\mathrm{y} \times 1.19 \times 100$
Where,

$\mathrm{y}=$ titre value $(\mathrm{ml}) \times 0.00195$

\section{Statistical analysis}

Completely randomized design (CRD) was used to analyse the data. The statistical procedures for agricultural research given by Gomez and Gomez (1976) were referred.

\section{Results and Discussion}

\section{Effect on moisture content}

The results showed that the average initial moisture content before irradiation was 10.60 per cent. The moisture content after first month of storage of irradiated foxtail millets ranged from 10.48 to 10.34 per cent (d.b), whereas the highest moisture content was recorded in control (10.50 per cent). It was also observed that for all the treatments there was a decrease in the moisture content with the increase in storage period and increase in irradiation dosage as shown in Figure 1.

The maximum moisture content after 6 months of storage was 9.83 per cent in control, whereas the minimum was 9.68 per cent in treatment $\mathrm{T}_{8}$ which was statistically on par with treatment $\mathrm{T}_{7} \quad(9.70$ per cent $)$ and treatment $T_{6}$ (9.71 per cent).After irradiation the decrease in moisture content might be attributed to the radiolysis of water by irradiation (Pankaj, 2013).Similar results were recorded by Bamidele and Akanbi(2013) who found that the initial moisture content of irradiated pigeon pea flour was 6.22 to 7.99 per cent and after irradiation, moisture content decreased to 6.00 to 7.50 per cent for $20 \mathrm{kGy}$. Saad and Kabbashi (2014) reported that, before irradiation the moisture content of composite flour (wheat and sorghum) as 9.84 per cent and after irradiation gradually decreased to 9.66 per cent for $8.00 \mathrm{kGy}$. 


\section{Effect on carbohydrates}

As shown in Figure 2, it is revealed from the results that the initial carbohydrate content of foxtail millets after irradiation was found to be 64.76 per cent for all the samples. It was observed that for all the treatments there was an increase in the carbohydrate content with increase in storage period. There was a significant difference in the carbohydrate content of foxtail millets during initial, $1^{\text {st }}, 2^{\text {nd }}$, $3^{\text {rd }}, 4^{\text {th }}, 5^{\text {th }}$ and $6^{\text {th }}$ month of storage. The minimum carbohydrates after six months of storage was recorded in control as 65.82 per cent and higher level of carbohydrates was observed in treatment is $\mathrm{T}_{8}$ (65.98 per cent) which was statistically on par with $\mathrm{T}_{7}(65.96$ percent) and $\mathrm{T}_{6}$ (65.94 per cent).Similar results were reported by Anwar et al., (2015) for wheat grains, the carbohydrate content before irradiation was found to be 72.67 per cent and after irradiation increased upto 72.70 per cent at $9.00 \mathrm{kGy}$. The increase in carbohydrate content after irradiation could be due to depolymerization of polysaccharides by radiolysis of starch.

\section{Effect on crude protein}

It was observed that the initial crude protein content of foxtail millets was found to be 12.23 per cent and after irradiation crude protein content of foxtail millet ranged from 12.04 to 11.93 per cent as compared to 12.08 per cent in control after first month of storage. After 6 months of storage there was a significant difference in protein content of foxtail millets as shown in Figure 3. The maximum crude protein content after 6 months of storage was 11.35 per cent in control, whereas, minimum was 11.20 per cent in treatment $\mathrm{T}_{8}$ which was statistically on par with treatments $T_{7}$ (11.21 per cent) and $T_{6}$ (11.23 per cent). Lee et al., (2005) reported that the gamma irradiation affected the proteins by causing conformational changes, oxidation of amino acids, rupturing of covalent bonds and formation of protein free radicals. Kabbashi et al., (2012) found a similar difference between untreated (control) and irradiated samples of wheat flour. They found that the protein content of wheat flour (control) was 13.67 per cent while the sample treated with $3 \mathrm{kGy}$ was 11.43 per cent.

\section{Effect on crude fat}

It was observed that for all the treatments there was a decrease in the crude fat content with increase in storage period as shown in Figure 4. The results showed that the initial fat content of irradiated dehusked foxtail millets was 4.38 per cent. The fat content after first month of storage ranged from 4.20 to 4.11 per cent, whereas the highest was recorded in control as 4.26 per cent $\left(\mathrm{T}_{0}\right)$. It was also observed that for all the treatments there was a decrease in the fat content with increase in storage period and also the fat content decreased with increased dosage. The maximum fat content after 6 months of storage was 3.48 percent in control, whereas the minimum was 3.34 per cent in treatment $\mathrm{T}_{8}$ which was statistically on par with treatments $\mathrm{T}_{7}$ (3.35 per cent), $\mathrm{T}_{6}$ (3.37 per cent). It was observed that there was a decrease in the crude fat with increase in storage period. This decrease in fat might be due to the radiolytic degradation of fat. Because fat is more sensitive to irradiation and after irradiation, radiolytic degradation of lipid takes place.

The crude fat of fresh wheat germ was found to be 10.94 per cent and it gradually decreased upto 10.57 per cent at $30 \mathrm{kGy}$ (Pankaj et al., 2013). The present results were also similar to the result reported by Tresina and Mohan (2012), for fat content of cowpea seeds. Initially it was found to be 4.68 per cent but after irradiation treatment at $25 \mathrm{kGy}$ it decreased to 3.21 per cent. 


\section{Effect on fibre}

It was observed that the initial crude fibre content after irradiation of foxtail millets was found to be 6.05 per cent. The crude fibre content of dehusked foxtail millets after first month of storage ranged from 5.88 to 5.77 per cent, whereas the highest was recorded in control as 5.92 per cent. It was observed that for all the treatments there was a decrease in the fibre content with the increase in storage period and decreased with increase in dosage as shown in Figure 5. The maximum fibre content after 6 months of storage was 5.19 per cent in control, whereas the minimum was 5.03 per cent in treatment $\mathrm{T}_{8}$, which was statistically on par with treatment $\mathrm{T}_{7}$ (5.04 percent), $\mathrm{T}_{6}$ (5.06 per cent).The fibre content decreases as the storage time increases. The irradiation dose dependent decrease in fibre on irradiation has been attributed to depolymerization and delignification of the plant matrix (Bhat et al., 2008). Bamidele and Akanbi (2013) reported that these results were in good agreement with the pigeon pea flour, the fibre content of pigeon pea flour was found to be 5.59 per cent but after irradiation at $20 \mathrm{kGy}$ it was reduced to 3.77 per cent. Similar results were reported by Tresina and Mohan (2012) for cowpea, as the crude fibre content of cowpea was found to be 5.58 g.100 $\mathrm{g}^{-1}$ before irradiation, but it was reduced to $3.54 \mathrm{~g} .100 \mathrm{~g}^{-1}$ after irradiation at $25 \mathrm{kGy}$.

\section{Effect on total ash}

It was observed that the initial total ash content of foxtail millets after irradiation was found to be 1.95 per cent. The total ash content of foxtail millets after first month ranged from 1.86 to 1.95 per cent, whereas the lowest was recorded as control as 1.83 per cent. It was observed that for all the treatments there was a decrease in total ash content with the increase in storage period and increase with increase in dosage as shown in Figure 6.
The minimum total ash content after 6 months of storage period was 1.10 per cent in control, whereas the maximum was 1.28 per cent in treatment $\mathrm{T}_{8}$ which was statistically on par with treatments $\mathrm{T}_{7}\left(1.25\right.$ per cent), $\mathrm{T}_{6}(1.23$ per cent), $\mathrm{T}_{5}$ (1.24 percent) and $\mathrm{T}_{4}(1.22$ per cent).Results were comparable with the findings of Manjula et al., (2015) who reported the initial iron and calcium content of the finger millet flour were 9.96 and 418 mg. $100 \mathrm{~g}^{-1}$ respectively and after irradiation treatment it was increased to 10.24 and 495.81 $\mathrm{mg} .100 \mathrm{~g}^{-1}$ respectively.

\section{Effect on total phenols}

It was observed that for all the treatments there was increase in the phenolic content with increase in storage period as shown in Figure 7. It was observed that the initial phenols content of foxtail millet was found to be 16.24 mg. $\mathrm{g}^{-1}$ and total phenols content after first month of storage of foxtail millets ranged from 16.40 to $16.54 \mathrm{mg} \cdot \mathrm{g}^{-1}$, whereas the lowest was recorded in control as $16.36 \mathrm{mg} \cdot \mathrm{g}^{-1}$. The maximum phenols content after 6 months of storage was $17.46 \mathrm{mg} \cdot \mathrm{g}^{-1}$ which was statistically on par with treatments $\mathrm{T}_{7}\left(17.44 \mathrm{mg} \cdot \mathrm{g}^{-1}\right)$ and $\mathrm{T}_{6}\left(17.42 \mathrm{mg} \cdot \mathrm{g}^{-1}\right)$ and the lowest was recorded as $17.30 \mathrm{mg} . \mathrm{g}^{-1}$ in control (unirradiated).

The reason for increase in total phenols is that as the dosage concentration increased there was increase in total phenols to higher extractability by depolymerization and dissolution of cell wall polysaccharides by irradiation (Adariano et al., 2012). The results are in good agreement with those of Singh et al., (2014) for legume seeds (chick pea, lentils and mung bean). Initially total phenols was found to be 2.14, 3.5, $5.8 \mathrm{mg} . \mathrm{g}^{-1}$ for chick pea, lentils and mung bean respectively and after irradiation treatment at2.00 kGy it was increased to $2.32,3.71$ and $5.97 \mathrm{mg} . \mathrm{g}^{-1}$ for chick pea, lentils and mung bean respectively. 
Fig.1 Effect of dosage of gamma irradiation on moisture content of foxtail millets during storage

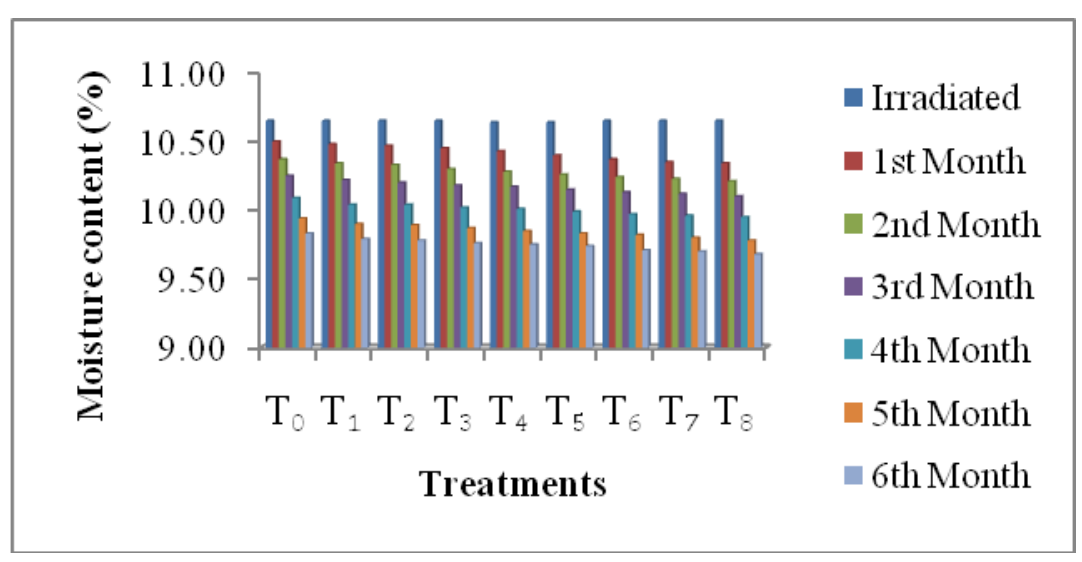

Fig.3 Effect of dosage gamma irradiation on crude protein of foxtail millets during storage

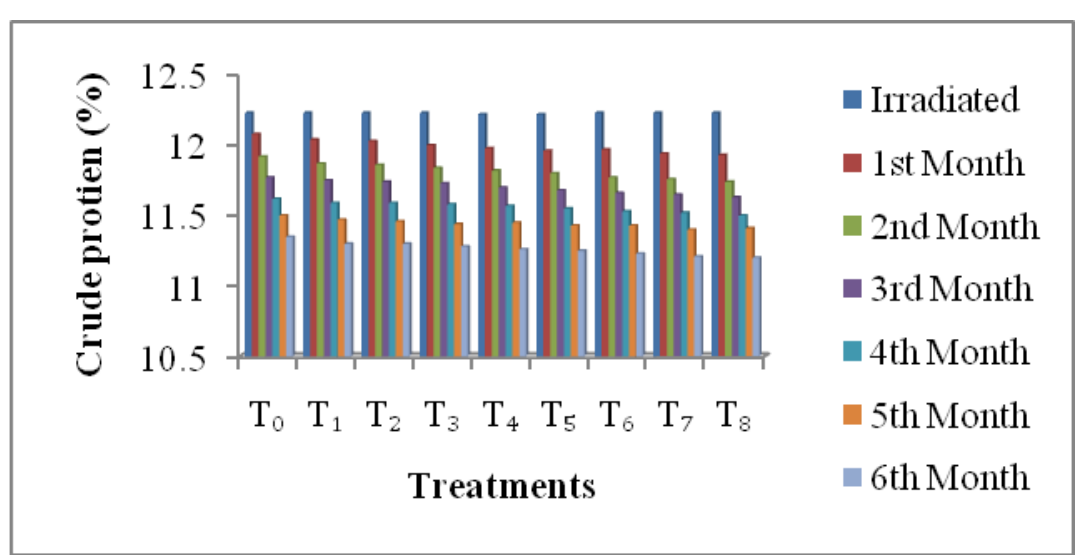

Fig.2 Effect of dosage of gamma irradiation on carbohydrates of foxtail millets during storage

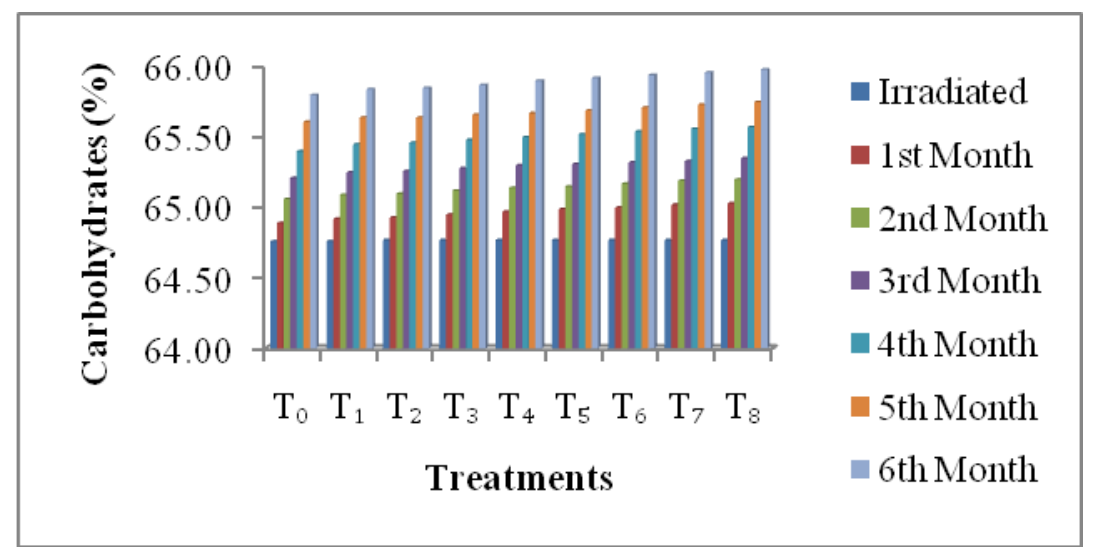

Fig.4 Effect of dosage gamma irradiation on crude fat content of foxtail millets during storages

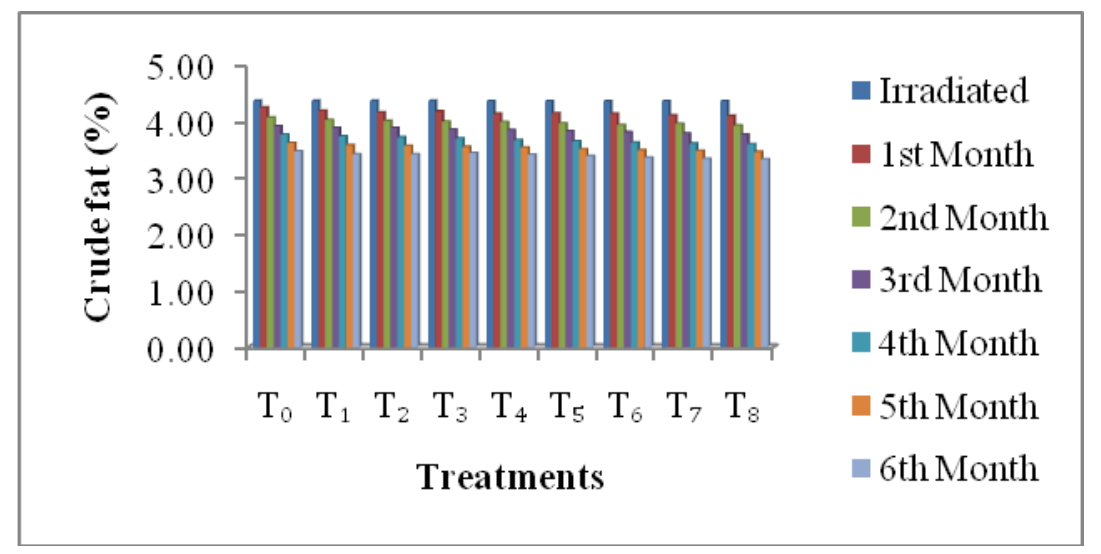


Fig.5 Effect of dosage of gamma irradiation on crude fibre of foxtail millets during storage

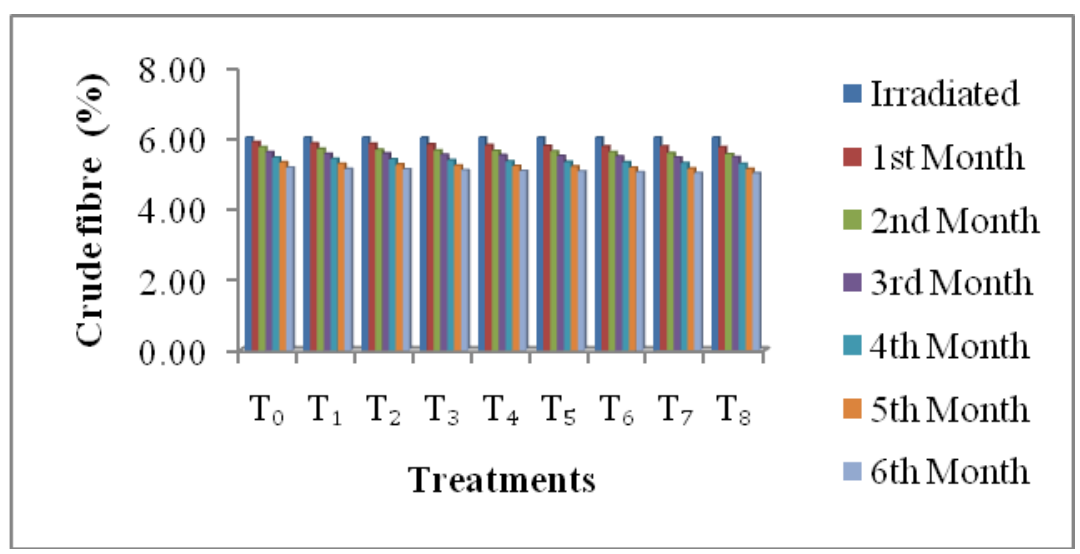

Fig.7 Effect of dosage of gamma irradiation on total phenols of foxtail millets during storage

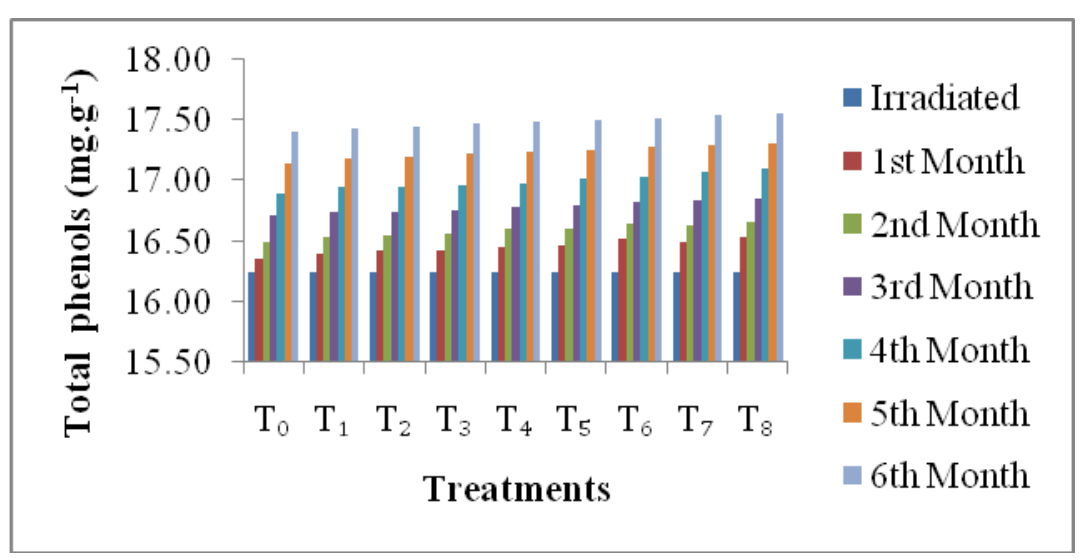

Fig.6 Effect of dosage of gamma irradiation on total ash of foxtail millets during storage

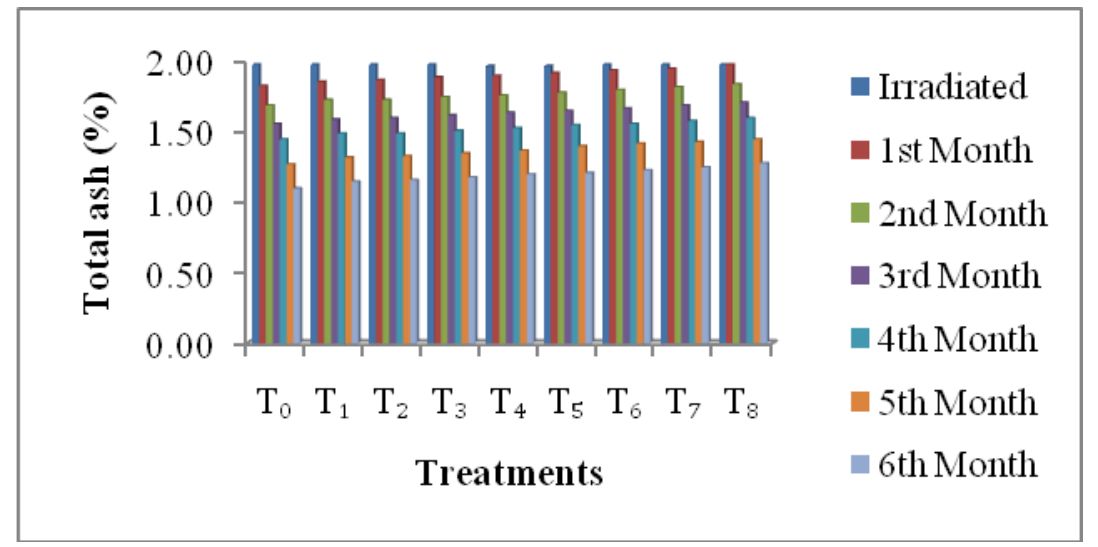

Fig.8 Effect of dosage of gamma irradiation on tannin content of foxtail millets during storage

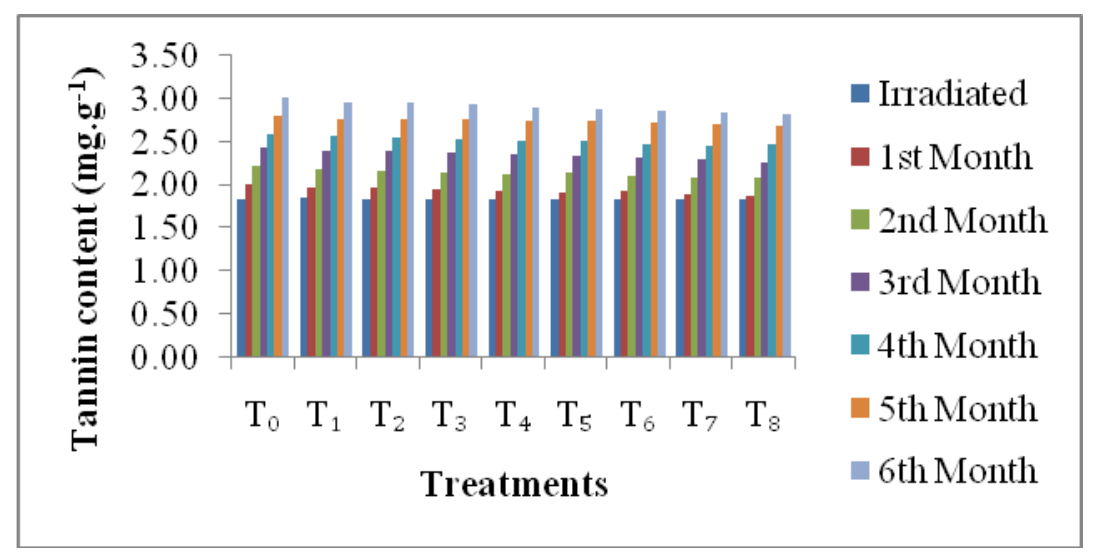


Fig.9 Effect of dosage of gamma irradiation on phytic acid of foxtail millets during storage

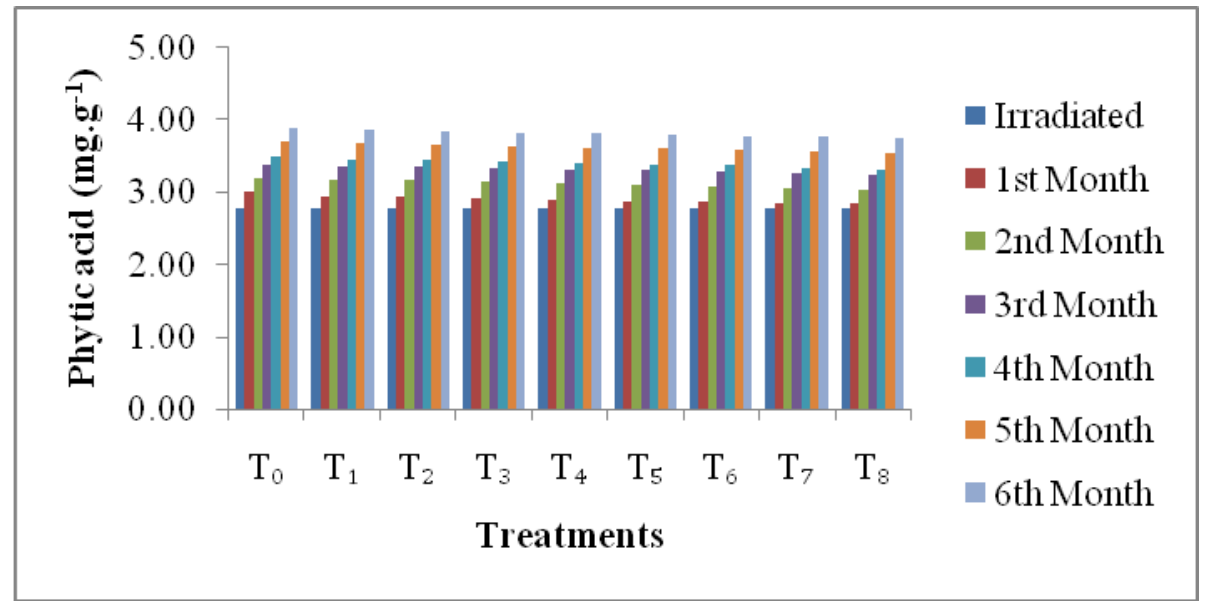

\section{Effect on tannin}

It was observed that the initial tannin content of dehusked foxtail millets was found to be $1.84 \mathrm{mg} \cdot \mathrm{g}^{-1}$ and tannin content after first month of storage ranged from 1.97 to 1.88 $\mathrm{mg} \cdot \mathrm{g}^{-1}$, whereas the highest was recorded in control as $\left(2.01 \mathrm{mg} \cdot \mathrm{g}^{-1}\right)$. It was observed that for all the treatments there was a increase in the tannin content with increase in storage period and decreased with increase in irradiation dosage as shown in Figure 8. The maximum tannin content after 6 months of storage was $3.01 \mathrm{mg} . \mathrm{g}^{-1}$ in control whereas minimum was $2.82 \mathrm{mg} . \mathrm{g}^{-1}$ which was statistically on par with treatment $\mathrm{T}_{7}(2.84$ $\left.\mathrm{mg} \cdot \mathrm{g}^{-1}\right)$ and $\mathrm{T}_{6}\left(2.86 \mathrm{mg} \cdot \mathrm{g}^{-1}\right)$.

The decrease in tannin content as the dosage increased might be due to chemical degradation by the action of free radicals formed during the radiation (Nagat et al., 2015). The results are in agreement with the findings of Rousta et al., (2014) for sorghum grain, initially it was found to be $921 \mathrm{mg} .100$ $\mathrm{g}^{-1}$ but after irradiation it decreased to 191 mg. $100 \mathrm{~g} \mathrm{~g}^{-1}$ at $30 \mathrm{kGy}$ dosage. Chamani et al., (2014) reported that changes in tannin content of gamma irradiated sorghum grains. They found that the tannin content of unirradiated sorghum grain was found to be $82.50 \mathrm{mg} .100$ $\mathrm{g}^{-1}$ and after irradiation at $30 \mathrm{kGy}$ it was reduced to $13.20 \mathrm{mg} .100 \mathrm{~g}^{-1}$.

\section{Effect on phytic acid}

It was observed that for all the treatments there was an increase in the phytic acid content with increase in storage period and decreased with increased dosage as shown in Figure 9. It was observed that the initial phytic acid content of foxtail millets was found to be initially $2.78 \mathrm{mg.g} \mathrm{g}^{-1}$ and after first month of storage ranged from 2.95 to $2.85 \mathrm{mg} \cdot \mathrm{g}^{-1}$, whereas the highest was recorded in control as $3.00 \mathrm{mg} . \mathrm{g}^{-1}$. The minimum phytic acid content after 6 months of storage was $3.75 \mathrm{mg} . \mathrm{g}^{-1}$ which was statistically on par with treatment $\mathrm{T}_{7}\left(3.77 \mathrm{mg} . \mathrm{g}^{-1}\right)$ and $\mathrm{T}_{6}\left(3.78 \mathrm{mg} \cdot \mathrm{g}^{-1}\right)$ and the highest was recorded as $3.90 \mathrm{mg} . \mathrm{g}^{-1}$ in control. The reduction in phytic acid during radiation process might be due to chemical degradation of phytate to the lower inositol phosphates and inositol by the action of free radicals produced by radiation or might be due to cleavage of the phytate ring itself (Hania et al., 2007). Results were comparable with the findings of Bamidele and Akanbiet al., (2013) who reported the initial phytic acid content of pigeon pea flour was found to be $94.67 \mathrm{mg} . \mathrm{g}^{-1}$ in control but after irradiation treatment it decreased to $25 \mathrm{mg} \cdot \mathrm{g}^{-1}$ at $20 \mathrm{kGy}$ dosage. 
This study investigated the effect of gamma irradiation on the quality parameters (moisture content, carbohydrates, crude protein, crude fat, crude fibre, total ash, total phenols, tannin and phytic acid) of dehusked foxtail millets. The proximate composition viz., moisture content, carbohydrates, crude fat and total ash of foxtail millets in treatment $\mathrm{T}_{8}$ were found to be higher compared to other treatments followed by treatment $T_{7}$. The anti-nutritional properties of the treated foxtail millets, the total phenols was found to be maximum, tannin content and phytic acid were found to be minimum in treatment $\mathrm{T} 8$. It was observed to be the best treatment as compared to other treatments

\section{Acknowledgements}

The authors thank for Department of Processing and Food Engineering, and Agricultural Research Station, Kalaburagi, UAS, Raichur, Karnataka, India to provide the facility to carry out the experimental work.

\section{References}

Adriano, C., Vieira, T. M. F. D. S., Regitano, D. A., Calori, D. M. A. and Brazaca, C. S. G., 2012, Gamma radiation effects on peanut skin antioxidants. Int. J. molecular sci., 13(3): 3073-3084.

Ai-Kaisey, M. T., Mohammed, M. A., Alwan, A. K. H., Mohammed, M. H., 2002, The effect of gamma irradiation on the viscosity of two barley cultivars for broiler chicks. Radiat. Phys. Chem., 63(1): 295-297.

Anwar, M. M., Asael, M. A. and El-Adly, N. A., 2015, Gamma radiation influence on rheological and technological characteristics of wheat flour and sensory properties of pan bread. $J$. Nucl. Technol. Appl. Sci., 3(2): 89-97.

AOAC, 2005, Official methods of analysis $\left(16^{\text {th }}\right.$ Edi.). Association of official analytical chemists, Washington, DC.

Arthur, F. H., 1996, Grain protectants: current status and prospects for the future. $J$. Stored Prod. Res., 32(4): 293-302.

Bamidele, O. P. and Akanbi, C. T., 2013, Influence of gamma irradiation on the nutritional and functional properties of pigeon pea (Cajanus cajan) flour. African J. Food Sci., 7(9): 285-290.

Bhat, R., Sridhar, K. R. and Tomita, Y., 2007, Effect of ionizing radiation on antinutritional features of velvet bean seeds (Mucuna pruriens). Food Chem., 103(3): 860-866.

Bhat, R. and Sridhar, K. R., 2008, Nutritional quality evaluation of electron beamirradiated lotus (Nelumbo nucifera) seeds. Food Chem., 107(1): 174-184.

Byun, M. W., Lee, J. W., Yook, H. S., Jo, C. and Kim, H. Y., 2002, Application of gamma irradiation for inhibition for inhibition of food allergy. Radiat. Phys. Chem., 63(3): 369-370.

Chamani, M. R., Sadeghi, A. A., Shawrangi. M. and Aminafshar, M., 2014, Changes in anti-nutritional contents and digestibility of gamma irradiated sorghum grains. Int. J. Biol. Pharm. Allied sci., 3(9): 2176-2187.

Chaturvedi, A., Padmavathy, T. V. N., Babu, D. J. and Sharma, A. K., 2013, Effect of radiation on nutritional quality, shelf-life and acceptability of ragi (Eleusine coracana) and barley (Hordeum vulgare). Adv. Appl. Sci. Res., 4(4): 11-16.

Cherry, A. J., Abalo, P. and Hell, K., 2005, A laboratory assessment of the potential of different strains of the entomopathogenic fungi Beauveria bassiana, Vuillemin and Metarhizium anisopliae to control Callosobruchus maculates, in stored cowpea. J. Stored Prod. Res., 41(3): 295-309.

Diehl, J. F., 2002, Food irradiation - past, present and future. Radiat. Phys. 
Chem., 63(3): 211-215.

Fombang, E. N., Taylor, J. R. N., Mbofung, C. M. F. and Minnaaar, A., 2005, Use of gamma irradiation to alleviate the poor protein digestibility of sorghum porridge. Food Chem., 91(4): 695-703.

Gomez, K. A. and Gomez, A. A., 1976, Statistical procedures for agricultural research. A Wiley Inter. Sci. Publ., New York.

Hania, F. G. and El-Niely., 2007, Effect of irradiation on anti-nutrients, in vitro protein digestibility and protein efficiency of legume seeds. Radiat. Phys. Chem., 76(6): 1050-1057.

Jyoti, P. M., Sukalyan, C., Sandeep, K., Subrata, P., Jiin-shuh, J., Alok, C. S., Anindita, C. and Subhas, C. S., 2009, Effect of gamma irradiation on edible seed protein, amino acids and genomic DNA during sterilization. Food Chem., 114(3): 1237-1244.

Kabbashi, E. E. B., Ahmed, E. G., Aljack, S. A., Hamad, S. A., Ahmed, M. E. and Elmamoun, K., 2012, Use of gamma irradiation for the control of the red flour beetle (TriboliumCastaneumHrbst) in bread flour. J. Radiat. Res. Appl. Sci., 5(4): 905-914.

Khalid, B. and Manjeet, A., Effect of gamma irradiation on cereals and pulses. Int. J. Recent Sci. Res., 7(12): 14680-14686.

Lee, S. L., Lee, M. S. and Song, K. B., 2005, Effect of gamma irradiation on the physico-chemical properties of gluten films. Food Chem., 92(4): 621-625.

Malleshi, N. G. and Desikachar, H. S. R., 1985, Milling, popping and malting characteristics of some minor millets. J. Food Sci. Technol., 22(1): 400-403.

Manjula, K., Bhagath, Y. B. and Nagalakshmi, K., 2015, Effect of radiation processing on bioactive components of finger millet flour (Eleusine coracana
L.). Int. Food Res. J., 22(2): 556-560.

Nagat, S., Mohmoud., Sahar, H. A., Rayan, M. A., Madani, Fahmi, A., Osman and Khalid, E., 2015, Effect of gamma radiation processing on fungal growth and quality characteristics of millet grains. Food Sci. Nutr., 4(3): 342-347.

Nirmala, P., Rashmi, M. A., Jayalaxmi, N. H., Jagadish, P. S. and Neelu, N., 2009, Impact of physical properties of foxtail millet grains on the growth and development of rice moth, Corcyra cephalonica. Karnataka J. Agric. Sci., 22(3): 672-673.

Oelke, E. A., Oplinger, E. S., Putnam, D. H., Durgan, B. R., Doll, J. D. and Undersander, D. J., 1990, Millets in alternative field crops manual, University of Wisconsin-extension, cooperative extension. 9(1): 60-68.

Pankaj, J. K., Kudachikar, V. B. and Kumar, S., 2013, Lipase inactivation in wheat germ by gamma irradiation. Radiat. Phys. Chem., 86(1): 136-139.

Price, M. L., Socoyoc, V. and Butter, G. L., 1978, A critical evaluation of the vanillin reaction as an assay for tannin in sorghum grain. J. Agric. Food Chem., 26(5): 1214-1218.

Rousta, M., Sadeghi, A., Shawrang, P., Afshar, M. A. and Chamani, M., 2014, Effect of gamma, electron beam and infrared radiation treatment on the nutritional value and anti-nutritional factors of sorghum grain. Iranian $J$. Appl. Animal Sci., 4(4): 723-731.

Saad, R. M. and Kabbashi, E. B. M., 2014, Impacts of gamma irradiation on composite flour quality. Int. Con. Radiat. Res. Appl. Sci., 3(1): 11-20.

Singh, P. K., Sohani, S., Panwar, N. and Bhagyawant, S. S., 2014, Effect of radiation processing on nutritional quality of some legume seeds. Int. J. Biol. Pharm. Res., 5(11): 876-881.

Sun, T., Powers, J. R. and Tang, J., 2007, 
Evaluation of antioxidant activity of asparagus, broccoli and their juices. Food Chem., 105(1): 101-106.

Tresina, P. S. and Mohan, V. R., 2012, Physico-chemical and anti-nutritional attributes of gamma irradiated Vigna unguiculata (L.) Walp. Subsp.
Unguiculata seeds. Int. Food Res. J., 19(2): 639-646.

Wheeler, E. I. and Ferrel, R. E., 1971, Methods for phytic acid determining in wheat and wheat fractions. Cereal Chem., 48(1): 312-320.

\section{How to cite this article:}

Mala, R.S. Roopa Bai, Udaykumar Nidoni, H. Sharanagouda and Hanchinal, S.G. 2019. Effect of Gamma Irradiation on Nutritional Quality Parameters of Dehusked Foxtail Millet (Setaria italica (L.) Beauv.). Int.J.Curr.Microbiol.App.Sci. 8(11): 568-579.

doi: https://doi.org/10.20546/ijcmas.2019.811.069 